Јелица Р. Стојановић Универзитет Црне Горе

Филолошки факултет у Никшићу

\title{
СТАТУС СРПСКОГ ЈЕЗИКА И ЋИРИЛИЦЕ У ЦРНОЈ ГОРИ ДАНАС И НЕОПХОДНОСТ ЈЕДИНСТВА СРПСКОГ ЈЕЗИЧКОГ ПРОСТОРА
}

Циљ нашег рада је да укратко представимо какав је статус српског језика, ћирилице као српског писма, а у складу са тим и културе и народа, данас у Црној Гори, десетак година након што је почео пројекат антисрпске политике. За кратко вријеме, на формалном плану, створена је једна нова стварност, незаснована на историјском континуитету, друштвеним потребама, исконструисана форма надомјештена је суштини, политичка рјешења науци.

Кључне ријечи: српски језик, ћирилица, народ, језички идентитет, историја, Декларација, устав, закони, дискриминација.

Положај оног дијела народа у Црној Гори који се изјашњава као Срби, према свим реалним показатељима, на најнижем је могућем нивоу. Обесправљени су и дискриминисани по много основа, односно, такорећи, у свим сегментима који се тичу одржавања и уважавања њиховог националног, народносног, културолошког и језичког идентитета.

1. Показатељ велике дискриминације јесте присуство (заступљеност) у државним структурама и органима, нарочито у руководственом кадру, гдје је оних који су се изјаснили као Срби (према истраживањима из 2010. 
године $)^{1}$, процентуално 10-15 пута мање у односу на оне који су се изјаснили као Црногорци, што је огромна диспропорција у односу на опредјељење за националну припадност, док је оних који су се опредијелили као говорници српског језика око 10\% више него оних који су се изјаснили за име црногорског језика. Нпр., од државних службеника и намјештеника, 85 одсто су Црногорци, а свега је 4,2 одсто Срба. У Министарству културе има 40 запослених, од чега је 33 Црногораца, четворо Срба, у Министарству просвјете и науке запослено је 69 лица, а од тог броја је 54 Црногораца, шест Срба. У Министарству здравља ради 207 људи. Од тога је 185 Црногораца, 12 Срба, пет Муслимана, два Албанца, а троје радника се није изјаснило. У Агенцији за националну безбједност, од 450 службеника, само су тројица Срби. Међу судијама Уставног, Врховног, Апелационог и Вишег суда - Срба нема. Сви показатељи говоре да не постоји ни један директор Србин у основним и средњим школама, вртићима, домовима здравља и болницама у Црној Гори.

Зар је онда чудно што се број оних који се национално изјашњавају као Срби смањио између два посљедња пописа. Према попису из 2003. године национално се као Црногорци изјаснило се 43,16\% становништва, а 2011 44,98\%; као Срби 2003 - 31,99, а 2011 - 28,73. Да говори црногорским језиком 2003. године изјаснило се $21,96 \%$ становништва, а 2011 - 36,97; српским језиком 2003 $63,49 \%$, а $2011-44,98$.

2. Као друго, у Црној Гори приводи се крају, пред нашим очима, употреба и(ли) могућност употребе српског

Према истраживањима: Inicijativa mladih Fondacija za ljudska prava Institut za otvoreno društvo Crna Gora Predstavništvo Crna Gora Program. Monitoring poštovanja ljudskih prava, Zastupljenost etničkih zajednica u državnim organimau Crnoj Gori, Inicijativa mladih za ljudska prava, Crna Gora, www.yihr.me, Podgorica, maj 2010. godine. 
језика, са тенденцијом да потпуно нестане са службене и јавне сцене, односно да нестане имена српског језика. Српски језик и књижевнојезичко насљеђе у Црној Гори покушавају се подвести под црногорски језик и црногорско књижевно насљеђе, покушавају се промијенити и фалсификовати историјски токови, и створити нова Црна Гора, која нема везе са собом, својом историјом, покушава се исфабриковати Црна Гора са „новим човјеком“, којем треба избрисати памћење, историју, здрав разум, - а тиме и душу. То је и циљ садашње политике у Црној Гори створити нову Црну Гору и у њој новог човјека, оштрицом самозабране и самозаборава.

Говорници српског језика се, не само обесправљују, него су потпуно обесправљени, корак по корак одузимају им се (сва) основна права.

„Црногорски језик“ је инаугурисан формалноправно, прављењем дубокох политичко-административних резова, почев од школског система, преко Устава, разних законских и подзаконских аката, а све је то пројектовано са намјером да се политичко-идеолошке одлуке, мало по мало, наметну свим грађанима Црне Горе различитим методама, што се данас приводи, ако овако настави и ако не наиђе ни на какав одговор, крају. Године 2007. изгласан је нови устав када је црногорски језик проглашен за „службени“ у Црној Гори, а српски, босански, хрватски за језике у „службеној употреби“. Та вјештачки створена разлика послужиће као „покриће“ за дискриминацију српског језика и говорника српског језика - потом. Јер, разлике, суштинске, између појмова „службени језик“ и „језик у службеној употреби“ нема. Међутим, то је био начин да се српском језику, односно његовом имену, одузму сва права. И оно што је у формално-правном дијелу српски језик и задржао („језик у службеној употреби“; „уклопљеност“ и сабијеност у оквиру четвороименог назива наставног предмета у основним и средњим школама: „Црногор- 
ски-српски, хрватски, босански“), настоји се да се смањи и уништи, прећути и игнорише, свакодневно, у пракси. Све што подразумијева службену и јавну употребу језика, Влада, министарства, Универзитет Црне Горе, просвјетне и културне структуре, итд., све је формализовано именом за језик „црногорски“. Циљ је навикнути цијелу Црну Гору на друго име за језик - „црногорски“, на тај начин што они који су одабрали да су говорници српског језика неће имати формалну потребу и прилику да са срећу са именом српског језика да би функционисали у систему Црне Горе. И не само да неће имати формалну потребу, него неће имати ни могућност да то своје суштинско право искористе и спроведу.

У школама није усаглашен назив наставног предмета (који је, такав какав - четвороимени) са оним што је на корицама уџбеника (а на корицама уџбеника пише „Црогорски“). Најновији моменат који је ових дана на дјелу јесте промјена назива предмета Српски језик на филолошким програмима за проучавање страних језика (енглеског, руског, њемачког, француског, италијанског) на Филолошком факултету у Никшићу, Универзитета Црне Горе, у нов назив Црногорски језик (као и предмета: Превођење са енглеског, руског..., на „црногорски“ и обрнуто, са „црногорског“ на те језике). Ако се тај „наум“ спроведе, ни један студент који се упише да студира енлески, руски, француски, њемачки..., неће моћи да искористи своје право, као неко ко се опредијелио за српски језик и његово име, а такође нити иједан предавач на тим студијским програмима.

У Црној Гори своје „уточиште“ српски језик има једино на Студијском програму за српски језик и књижевност на Филолошком факултету у Никшићу, потпуно изолован и усамљен. А који већ годинама, откад је инаугурисан црногорски језик (и отворен студиј, потом и факултет за исти) покушавају да затворе, преименују и 
сл. Међутим, упркос свему, Студијски програм за српски језик има препознатљиви научни кадар, који му остаје вјеран, и студенте који у овом времену студирају језик који има научну заснованост и историјску препознатљивост и континуитет у Црној Гори.

3. Што се тиче статуса ћирилице у Црној Гори, ћирилице је готово сасвим нестало из нашег видокруга, све око нас је (осим, можда, једва 2\% натписа разног типа) латинично, сва администрација, сва коресподенција са државним (општинским, просвјетним, културним...) органима и институцијама је на латиници. ${ }^{2}$ Само у неким дјеловима постоји могућност да грађани затраже (што почесто подразумијева попуњавање одређеног формулара) да му нешто буде „издато“ на ћирилици: лична документа (нпр.), а у новије вријеме и школска свједочанства. С тим што се латиница подразумијева, чиме је право употребе, и право добијања ћирилице већ маркирано, тј. обиљежено. То многе у Црној Гори, с обзиром на могуће, а и посвједочене посљедице, које грађани Црне Горе трпе свакодневно, обесхрабрује да се опредијеле за ћирилицу. Црна Гора је, тиме, прва православна земља која ћирилицу замјењује латиницом. Шта је узрок томе и које су посљедице очекиване (или задате), није тешко процијенити.

Након овог кратког представљања постаје јасно зашто се између два пописа смањио број оних који се национално изјашњавају као Срби, а још више оних који су се опредијелили за српски језик. И, ако се оваква дискриминација и непоштовање основних права наставе, поставља се питање шта ће бити даље... Сјетимо се не тако давних времена и не тако удаљених простора, и сјетимо се како се смањивао број оних који су се национално изјашњавали као Срби. И, да ли српски корпус и у Црној Гори треба свести на симболичан број да би им

2 Видјети: Стојановић 2016. 
се, потом, симболично и (дарежљиво) услишила права. Свакако, Црна Гора се, својим историјским насљеђем и својом дубоком истином негдје изнутра свему томе одупире и од свих лажи и импровизација брани, али и ми, лично, у малом као и у великом, морамо бити одговорни и учинити макар неки напор да спријечимо дискриминацију, те да се изборимо за достојанство онога што има континуитет, утемељеност и историјску препознатљивост - српског језика, ћирилице, српског културног и народносног бића у Црној Гори.

Дакле, без обзира на све, шта би требало да је обавеза државе Црне Горе према Уставу и законима: српски језик је, према Уставу, у службеној употреби, а службена употреба треба да подразумијева готово све. Уз то, српски језик је и већински језик у Црној Гори, опет, без обзира на све притиске (који, ипак, постепено, дају резултате), што је јединствен примјер у свијету свих времена - да већински језик нема готово никакав статус. Као друго: и према Уставу ћирилица и латиница су равноправна писма (при чему, ипак, ћирилица стоји на првом мјесту). А при том, и упркос свему, ћирилица је, као и српски језик, осим у Уставу, који је некад све (када одговара власти), некад ништа (као у случају српског језика и ћирилице), мртво слово на папиру. Дакле, ако се само поштује Устав Црне Горе, говорници српског језика и ћирилица задовољиће своја основна права. Али, како доћи до тога да се поштују основна права у Црној Гори? Да не кажемо да се поштују наука и струка, као и историјско-научна истина, јер је то већ друго и посебно питање, него да се поштују основна Уставом загарантована, при том и људска, и лична права?!

Црна Гора и њено језичко насљеђе су саставни дио широког српског континуума и то се не треба и не смије заборављати. Међутим, почесто се стиче утисак да је Црна Гора препуштена сама себи, занемарена, да не кажем заборављена у том ширем континууму. 
4. Посебан културолошки феномен јесте покушај да се фалсификује историја и насљеђе Црне Горе. Кроз сву историју, књижевно-језичко и културолошко насљеђе у Црној Гори, носило је српски предзнак. Данас се покушава све, ретроактивно, подвести под црногорско и избрисати му посвејдочено српско име. Наиме, језик на просторима који су данас у саставу Црне Горе, а који су кроз историју припадали разним (превасходно) српским формацијама, кад се именовао, именовао се као српски. Такође и етнос и писмо носили су српски предзнак. Међутим, данас се све писано насљеђе подводи под црногорско, почев од Мирославтьевоі јеванђетьа, Иловичке крмчије, Пашйровских исирава, итд., потом сви писци: Његош, Марко Миљанов, Стефан Митров Љубиша..., и тако редом, све до Матије Бећковића и Мира Вуксановића. Без обзира што су сами себе уградили у српску културу и посвједочили се српским именом.

5. Најновија декларација (тзв. Сарајевска декларација, о којој се ових дана доста говори) јесте још једно у низу поигравања науком, поготово историјским језичким насљеђем. То што се у Декларацији каже да је то један језик, то је, наравно, тачно: „Na pitanje da li se u Bosni i Hercegovini, Crnoj Gori, Hrvatskoj i Srbiji upotrebljava zajednički jezik - odgovor je potvrdan. Riječ je o zajedničkom standardnom jeziku policentričnog tipa - odnosno o jeziku kojim govori više naroda u više država s prepoznatljivim varijantama - kakvi su njemački, engleski, arapski, francuski, španjolski, portugalski i mnogi drugi. Tu činjenicu potvrđuju štokavica kao zajednička dijalekatska osnovica standardnog jezika, omjer istoga spram različitoga $u$ jeziku i posljedična međusobna razumljivost. Korištenje četiri naziva za standardne varijante - bosanski, crnogorski, hrvatski i srpski - ne znači da su to i četiri različita jezika“, стоји у Декаларацији.

Да је то један језик, србистика и српски лингвисти су одувијек знали и од тога нијесу одступали. Чак је и 
очигледно да је то један језик, према структурно-генетском коду, потом према комуникацијском критеријуму, ма како се језик именује сви се изузетно добро разумијемо. Али, најважније је питање, ако је је то један језик, који је то језик. Декларација, нажалост, полази од српскохрватског/хрватскосрпског, као да је то прапочетак свега. Као да прије тога није ништа постојало. Иако је то само једна епизода српског језика. Не каже се на основу чега је настао српскохрватски/хрватскосрпски. Основно је питање, како се тај језик (како што се тиче писаног насљеђа тако и што се тиче дијалекатске основице која је у основи стандардног/књижевног језика) именовао, као и каква је његова структура, које је његова колијевка. Као што је рекао Павле Ивић, штокавски дијалекат је настао на простору средњовјековне Србије. Дакле, то је онај један језик који је нормирао Вук Караџић „за Србе сва три закона“, и којег је Вук називао једино српским. Да је то један језик, ту дилеме нема, без обзира на вјештачке отклоне који се стварају покушајем уношења неких новина у вуковску норму. И колики год отклон да се направи у различитим центрима, не може се створити разлика (нити је створена) да би се могло радити о различитим језицима. Насупрот овоме у Декларацији стоји: „sve četiri trenutno postojeće standardne varijante ravnopravne su i ne može se jedna od njih smatrati jezikom, a druge varijantama tog jezika“. Међутим, српски језик, и његов стандард, нијесу варијанта нечега надређеног, већ су надређени свим изведеницама. Српски језик је сачувао своју верикалу, континуитет, и на дијалекатском плану, и као стандардни/књижевни језик, он није варирао у односу на нешто, није имало потребе да се прави вјештачки отклон. Као и сваки стандардизовани језик, и српски се осавремењава у складу са неминовношћу друштвенојезичких промјена. То су благе и потребне промјене. 
Међутим, норма српског језика није ишла ни за чим вјештачким, што је посведочено стабилношћу стандарда.

Даље, у Декларавцији се каже да се сваком оставља могућност да језик именује како жели, чиме се враћамо на самопрокламовано право које је створено од стране Хрвата шездесетих година 20. вијека, што је потом прихватано као „образложење“ за остала новонаименовања.

Углавном, питање је ко стоји иза Декларације и коме је намјењена. Чему би требало да послужи. Поучени досадашњим искуством, говорници српског језика и Срби не могу очекивати никакве добре намјере. Декларација, у суштини, будући како је срочена, има, прије свега, за циљ да српско писано, књижевно, језичко насљеђе преузме, подведе под савремена наименовања и пројекције, према државним, регионалним, националним пројекцијама, како би коме одговарало. Али, да се од српског насљеђе што је могуће више „очупа“. Иза ове декларације не стоји србистика, једва који изузетак. Као што видимо, ни Хрвати генерално не прихватају Декларацију, али они из других разлога. Они поричу непобитну чињеницу да је то један језик, јер је то за њих проблематично, а и болно. Мислим да је Декларација, прије свега „намијењена“ Србима, који би требало да прихвате да се српски може звати како ко хоће, а да Хрвати остану при именовању језика „хрватски“, а остали простори да остану при несрпским именима.

Шта би то требало да значи у Црној Гори?! Па то исто, само још драстичније, погубније и драматичније, историјски, а и на савременом друштвено-језичком плану, најишчашеније: да се српски језик не зове српским и да се српско језичко и књижевно насљеђе подведе под нешто друго што би, прије свега, требало да не буде српско.

6. Из свега реченог јасно је шта је резултат политичких резова у Црној Гори посљедњих десетак година: 
дошло је до конструисања нове језичке стварности, маргинализовања српског језика и пројектовања „црногорског језика", извршено је насиље над науком, над српским језиком, над језичком истином, над историјским континуитетом и насљеђем, ћирилица, као историјско писмо, на простору данашње Црне Горе, сведена је на најмању могућу мјеру. Процес је текао поступно: од васпитно-образовног система, преко Устава и законских аката, до покушаја стварања и наметања новог језичког стандарда и норме, са тежњом да се српски језик потисне, изостави, заобиђе, забрани, прећути. У складу са тим задатак србистике, као и институција и надлежних органа (који имају законску, професионалну, моралну и сваку другу обавезу и одговорност да се брину за статус српског језика), очување српског језичко-културног историјског насљеђа, његовање србистике на научној основи, брига о говорницима српског језика са свих простора, па и са простора Црне Горе. Србистика треба да се држи историјске вертикале, узимајући у обзир историјско име језика (тј. како се језик именовао на широком простору, узимајући у обзир и то којим се називима, који су данас актуелни, никад није именовао, или је именовање било спорадично и са другом конотацијом). У складу са тим треба да сабира, прикупља, баштини, пописује, описује, научно верификује богато и разноврсно насљеђе са цјелокупног српског језичког подручја у историјском континуитету, без обзира на новонастале национално-идеолошке и државотворне пројекте; у стандарду да и даље баштини вуковски српски књижевни модел; треба да његује и екавски и ијекавски изговор као равноправне; да истрајава на враћању достојног мјеста ћирилици као вјековно препознатљивом српском писму (узимањем у обзир и српско језичко насљеђе и на осталим писмима, - глагољици, латиници, арабици). Ово подразумијева ангажовање на свим пољима која су значајна за унапређење србистике 
и очување српског језика. Уз то, задатак србистике, а и језичке политике, а и политике шире, јесте и да не запоставља (да не кажем „прећуткује“) говорнике српског језика - са свих простора, да се ангажује на остваривању њихових права, да пружа подршку говорницима српског језика и српском језику (али стварну а не само вербалну, мада ми се чини да чак и вербална почесто изостаје). А језгро у Црној Гори постоји, дубоко је утемељено, опстаје, упракос свим недаћама, и одазваће се.

\section{Цитирана литература}

Декларација: http://www.lupiga.com/vijesti/tekst-deklaracije-ozajednickom-jeziku-govorimo-istim-jezikom (преузето, јун 2017).

Истарживање: www.yihr.me, Podgorica, мај 2010. godine (преузето мај 2017).

Стојановић 2016: Јелица Стојановић, Пуй срӣскоі језика и йисма, Српска књижевна задруга, Београд. 
Jelica R. Stojanović

University of Montenegro

Faculty of Philology in Nikšić

Study Program of Serbian Language and Literature

\title{
THE STATUS OF THE SERBIAN LANGUAGE AND CYRILLIC ALPHABET IN MONTENEGRO TODAY AND THE NECESSITY FOR THE UNIFIED SERBIAN LANGUAGE SPACE
}

\begin{abstract}
Summary
The aim of our work is to briefly present the status of the Serbian language, the Cyrillic alphabet as a Serbian letter, and accordingly Serbian culture and people, in Montenegro today, about ten years after the project of anti-Serbian politics began. In a short period of time, a new reality has been created on a formal plan, which is not based on historical continuity and social needs, and whereby the essence is replaced with fabricated form and science with political solutions.
\end{abstract}

Key words: Serbian language, Cyrillic alphabet, people, linguistic identity, history, Declaration, constitution, laws, discrimination. 